\title{
Vključevanje staršev $v$ zgodnje učenje matematike
}

\author{
Nataša Živkovič \\ Vrtec pri OŠ Istrskega odreda Gračišče \\ natasa.zivkovic13@gmail.com
}

Sanela Mešinović

Univerza na Primorskem

sanela.mesinovic@pef.upr.si

Svetovna javnost $v$ zadnjih letih posveča veliko pozornost matematični pismenosti. Številne raziskave so pokazale, da lahko matematična znanja napovejo prihodnost otrok. Vplivajo namreč na doseženo stopnjo izobrazbe, akademski uspeh, kvaliteto službe in določajo višino njihove plače. Po nekaterih raziskavah naj bi bila matematična znanja močni napovedovalci socialnoekonomskega statusa. Razvijanje matematične pismenosti je dolgotrajen proces, ki se začne že v predšolskem obdobju. Ravno v tem obdobju imajo starši in domače okolje največji vpliv na razvoj otrok in s tem matematičnega mišljenja, zato lahko sklepamo, da je vključevanje staršev v zgodnje učenje matematike nujno. $V$ ta namen smo izvedli raziskavo, s pomočjo katere smo starše seznanili z zgodnjo matematiko ter otrokom omogočili, da so nekatere koncepte raziskovali v interakciji s svojimi starši v domačem okolju. Ugotovili smo, da si starši želijo postati sooblikovalci otrokovega znanja ter da so z vrtcem pripravljeni sodelovati, vendar si želijo smernic, kako to storiti.

Ključne besede: predšolska vzgoja, zgodnja matematika, domače okolje, starši, matematični nahrbtnik

\section{Uvod}

Razvijanje matematičnega mišljenja je dolgotrajen proces, ki se začne že zelo zgodaj. Dojenček se uči matematiko, še preden je sposoben sedeti, saj opazi razlike v količini, med seboj primerja predmete po obliki in velikosti ter pri igri in vsakodnevnih opravilih uporablja nekatere matematične koncepte (Gopnik idr. 2001).

Številne raziskave kažejo, da ima zgodnje razvijanje matematičnih spretnosti velik vpliv na kasnejše matematične pa tudi bralne zmožnosti otrok (Clements in Sarama 2014; Duncan idr. 2007). M. N. McCain in Mustard (1999) trdita, da so izkušnje, ki jih otrok pridobi v predšolskem obdobju, ključnega pomena za njegove kompetence v prihodnosti, za učinkovito reševanje problemov, hkrati pa vplivajo na njegovo zdravje in kasnejše možnosti zaposli- 
tve. Podobno nam lahko srednješolske matematične sposobnosti napovedo številne uspehe $v$ odraslem obdobju, predvsem visoko stopnjo izobrazbe (Murnane, Willett in Levy 1995) ter kvalitetno službo in plačo (Rivera-Batiz 1992), kar vpliva na ekonomsko uspešnost države. Vzajemni učinek se je pokazal tudi med matematičnimi zmožnostmi ob samem začetku osnovnošolskega izobraževanja in kasnejšimi osnovnošolskimi dosežki (Claessens, Duncan in Engel 2009; Duncan idr. 2007). Dolgoletna raziskava je pokazala, da zgodnje matematične zmožnosti napovedujejo matematične dosežke otrok vse do doseženega petnajstega leta starosti (Watts idr. 2014). Tovrstna spoznanja so vzbudila zanimanja za splošno zagotavljanje predšolske vzgoje kot sredstva za izboljšanje pripravljenosti otrok na šolo in drugih dosežkov (Zigler, Gilliam in Jones 2006). Natančno in jasno določeni cilji poučevanja matematike $v$ vrtcu koristijo vsem otrokom, tudi tistim s posebnimi potrebami (Claessens, Engel in Curran 2014).

Kljub temu, da navedene raziskave dokazujejo močno povezanost med matematičnimi dosežki predšolskih otrok in matematičnimi dosežki srednješolcev, je potrebno opozoriti na dejavnike, ki lahko bistveno vplivajo na te dosežke. Dejavniki kot so motivacija, učenje in poučevanje, domače okolje ter zanimanje za matematiko lahko tako pozitivno kot negativno vplivajo na dosežke pri matematiki (Watts 2014).

\section{Teoretična izhodišča}

\section{Zgodnja matematika}

Izraz "zgodnja matematika« se nanaša na osnovne matematične koncepte, kot so štetje, količinski odnosi, geometrijske oblike, prostorski odnosi, merjenje, vzorci itn. Otroci so po naravi radovedni, zato te koncepte raziskujejo v interakciji s svojim okoljem (Sarama in Clements 2009; Ginsburg, Inoue in Seo 1999). O matematičnih konceptih se učijo v situacijah, ki so blizu njihovemu resničnem življenju. Preko lastnih aktivnosti pridobivajo matematične izkušnje, ki vključujejo tudi logično-matematično mišljenje. Konkretne izkušnje so temelj za razvijanje matematičnega mišljenja pri otroku in za kasnejše učenje abstraktnih pojmov. Samostojno raziskovanje konceptov pa kljub temu ne zadošča za usvajanje matematičnih pojmov, ki jih je otrok doživel - nujna je še vsakodnevna komunikacija z odraslimi. Zato moramo natančno razmisliti, kako otrokom zagotoviti matematične izkušnje in katera sredstva uporabiti, da bodo lahko razvijali svoje matematično mišljenje.

Jasno je, da je vloga odraslega pri raziskovanju matematičnih konceptov zelo pomembna. Njegova naloga je, da otroku pomaga prepoznati matematiko $v$ raznih aktivnostih in pri tem izhajati iz konceptov, ki jih otrok že pozna, 
ter graditi nova matematična znanja (Saxe, Guberman in Gearhart 1987). Matematične dejavnosti lahko vključimo v pesmi, ples, likovno umetnost, športne aktivnosti, igro vlog in domišljijsko igro itn.

Štetje je eno izmed pomembnejših matematičnih konceptov v predšolskem obdobju, saj zmožnost zgodnjega štetja pozitivno vpliva na osnovnošolske in srednješolske matematične zmožnosti otrok (Watts idr. 2014; Bailey, Siegler in Geary 2014; Jordan idr. 2009). Biti številsko pismen ne pomeni le prepoznavati števila, pač pa števila in štetje uporabljati v vsakodnevnem življenju. Taka pismenost nam dodatno omogoča, da lahko razmišljamo in komuniciramo matematično $v$ specifičnem matematičnem kontekstu (Anning in Edwards 2006). Številsko pismenost razvijamo že v predšolskem obdobju, saj poznavanje števil in njihova uporaba pripomore k razvijanju matematičnega mišljenja, kar pa je dolg in kompleksen proces.

P. Munn (1997a) je ugotovila, da lahko otrok izgovarja imena za števila v ustreznem vrstnem redu, vendar ne moremo zagotovo trditi, da ima številske predstave. Zato vzgojitelje opozarja, naj bodo pozorni na razvoj številske pismenosti pri otrocih. Številska pismenost ni tako očitna kot zgodnje opismenjevanje, saj je smiselna raba števil odvisna od razumevanja koncepta števil, ki ga to število predstavlja (Munn 1997b). Saxe idr. (1987) menijo, da lahko otroci številske predstave razvijajo le ob pomoči odraslega, ki jim pomaga pri uporabi obstoječih številskih spretnosti za reševanje kompleksnejših problemov, kar omogoča razvoj novih spoznanj. Pri tem je pomembno, da sta $v$ reševanje problemov vključena igra in razgovor. To otrokom zagotavlja, da reševanje poteka v njihovem jeziku - tako postane zanje problem rešljiv in lahko varno raziskujejo matematične izzive. Ko otroci usvojijo števila in pridobijo številske predstave, lahko raziskujejo druge matematične koncepte, povezane s števili, kot sta obdelava podatkov in merjenje.

Za razumevanje geometrije moramo imeti dobro razvito prostorsko predstavo, saj je ta nujna pri vizualizaciji, načrtovanju in konstrukciji oblik, geometrijskem pogledu na fizični svet ter uporabi znakov za prikaz nevizualnih matematičnih konceptov in odnosov (Mešinović, Cotič in Žakelj 2017).

Na zmožnost prostorske predstavljivosti vplivajo predvsem izkušnje, ki jih imamo z oblikami in s prostorskimi odnosi. Prve izkušnje pridobimo kmalu (ob rojstvu) - z opazovanjem in manipuliranjem konkretnih predmetov $v$ prostoru. Fizična dejanja ponotranjimo in posplošimo v koncepte ter odnose (Dickson, Brown in Gibson 1984).

Tako kot pri vpeljevanju števil in štetja je pri pridobivanju prostorskih predstav prisotnost odrasle osebe nujna. Njena naloga je, da izbere in ponudi ustrezne didaktične pripomočke, ki jih bo otrok uporabil pri igri in reševanju 
geometrijskih problemov. Sredstva, ki jih ponudimo otroku, morajo vzpodbujati miselni napor ter povečevati motivacijo za reševanje problema. $V$ nasprotnem primeru ima didaktično sredstvo funkcijo posrednika oz. primitivnega kalkulatorja (Hodnik Čadež in Manfreda Kolar 2009), v nekaterih primerih ima lahko celo škodljiv učinek na učenje in uspešnost (McNeil in Jarvin 2007).

\section{Starši in domače okolje}

Zgodnje učenje matematike $v$ vrtcu ni in ne sme biti le pripravljanje otrok na šolsko matematiko, ampak priložnost, da z otroki razvijamo njihovo lastno učinkovitost. S konkretnimi izkušnjami se neformalno učijo osnovne matematične koncepte, na katerih lahko $v$ osnovni šoli gradijo formalnejše in abstraktnejše koncepte.

Prvih nekaj let otrokovega življenja imajo starši in domače okolje največji vpliv na razvoj možganov, kar se kaže $v$ šolskem uspehu in na drugih področjih življenja (Harris in Petersen 2017). Posledično interakcija med starši in otrokom vpliva na zgodnje razumevanje matematike. Melhuish idr. (2008) so pokazali, da poleg socialno-ekonomskega statusa domače učno okolje pomembno vpliva na otrokove matematične dosežke. Otroci, katerih starši se zavedajo pomembnosti svoje vpletenosti $v$ učno okolje in so seznanjeni $z$ njihovimi dosežki, oblikujejo pozitiven odnos do šole in so učno uspešnejši (Epstein 1992). Bogata učna okolja, ki vključujejo pomembne matematične izkušnje, so povezana z višjimi dosežki otrok (Biddulph, Biddulph in Biddulph 2003).

Otroci v domačem okolju delujejo bolj sproščeno, saj so čustveno navezani na starše in se počutijo varne, zato so tudi zmožni izraziti svoje znanje, ki ga v neznanem okolju ne bi. Cai (2003) je pokazal, da je vpletenost staršev statistično pomemben napovedovalec matematičnega dosežka njihovih otrok, prav tako pa spodbuja pozitivno vedenje in čustveni razvoj.

Otroci, ki v času od 1 do 3 let živijo v spodbudnem matematičnem okolju, so ob vstopu v šolo uspešnejši pri razumevanju matematičnih konceptov kot otroci, ki v tej razvojni dobi nimajo matematično spodbudnega okolja (Berkowitz idr. 2016; Levine idr. 2010).

Spodbujanje matematičnega mišljenja je lahko za nekatere starše zelo zahtevna naloga, saj jo spremljajo anksioznost, nemoč, strah in odpor do matematike, ki izvirajo iz lastne negativne izkušnje oz. negotovosti glede svojih matematičnih znanj (Harris in Petersen 2017; Haylock 2007). Strah pred matematiko se lahko prenese na otroka, začetni vtisi pa imajo lahko dolgotrajne učinke (Cannon in Ginsburg 2008). Mnogo staršev trdi, da je matematika pomembna, vendar meni, da je dolgočasna, saj temelji na pomnjenju pravil in 
procedur (Onslow 1992). R. Pritchard (2004) je analizirala številne raziskave, ki poročajo, da obstajajo povezave med stališči in prepričanji staršev o matematiki ter med odnosom njihovih otrok do matematike. Odnos staršev do matematike pomembno vpliva tudi na uspešnost otrok pri tem predmetu (Pritchard 2004).

Da bi malčkom omogočili vsakodnevno razvijanje matematičnih zmožnosti, bi bilo potrebno (Cannon in Ginsburg 2008; Harris, Petersen in SmitherWulsin 2017):

- seznaniti starše z zgodnjimi matematičnimi koncepti in s pomenom vpeljevanja le-teh v starostnem obdobju od 1 do 3 let,

- staršem omogočiti pomoč pri premagovanju strahov pred matematiko in

- staršem ponuditi konkretne pripomočke, ki omogočajo učenje matematičnih konceptov skozi dnevno rutino $v$ domačem okolju.

Starši so pripravljeni vključiti zgodnje matematične elemente $v$ domače okolje, če vedo, kako to storiti (Starkey in Klein 2000). Starkey in A. Klein (2000) sta pokazala, da je seznanjanje staršev o metodah učenja matematike učinkovito, saj so bili otroci staršev, ki so bili deležni matematičnih delavnic, uspešnejši pri matematiki kot otroci staršev, ki se delavnic niso udeležili. Seznanjanje $z$ metodami učenja pripomore $k$ temu, da so starši samozavestnejši pri vključevanju matematičnih konceptov v življenjske situacije (Tye 1993) in aktivneje sodelujejo v procesu učenja svojih otrok (Morgan in Tremere 1993). J. Bernie in M.-C. Lall (2008) sta ugotovili, da vključevanje staršev v učenje matematike pozitivno vpliva na dosežke učencev, izboljša matematično znanje staršev, zvišuje vključenost staršev v šolsko življenje in splošno izobraževanje njihovih otrok.

Vzgojitelj ima veliko priložnosti, kjer lahko tesno sodeluje s starši in jih seznani z zgodnjo matematiko ter strategijami vključevanja le-te $v$ vsakodnevna domača opravila, ki zahtevajo prepoznavanje matematike $v$ realnih situacijah. Starši morajo imeti podporo s strani vzgojitelja, da bodo lahko svojim otrokom ponudili široko paleto matematičnih izkušenj, ki so smiselno vključene $v$ njihove aktivnosti ter jim ponujajo užitek in veselje. Zato se zdi v ozaveščanje staršev o pomembnosti zgodnjega učenja matematike in njihovo seznanjanje z osnovnimi koncepti koristno vlogati čas in sredstva.

\section{Raziskovalni problem}

Otrok večino časa preživi v vrtcu s svojimi vrstniki in vzgojitelji. V procesu socializacije in učenja sta domače in vrtčevsko okolje kot dva sistema preple- 
tena, zato je smiselno, da sodelujeta za dobrobit otroka. $V$ obdobju zadnjih nekaj desetletij se je razumevanje in pričakovanje vključevanja staršev v ustanove, kot je vrtec, precej spremenilo - od stroge prepovedi prihajanja staršev $v$ vrtec do današnjega sodelovanja in partnerstva med starši in vzgojitelji; slednje narekuje tudi trenutno veljavna zakonodaja, ki jo mora vzgojitelj izpolnjevati (Logar 2012, 37). Razlogi za sodelovanje so pomembni iz več razlogov, saj je otrok v predšolskem obdobju bolj kot kadarkoli pozneje povezan $z$ in odvisen od staršev. $V$ tem obdobju je zaradi tesne povezanosti med njimi največ možnosti, da vzgojitelj posredno vpliva na stališča staršev in jih lahko tudi spreminja (Kunič 2003, 13). Zato smo v okviru naše raziskave starše seznanili s predšolsko matematiko, jim omogočili, da prepoznajo matematiko $v$ življenjskih situacijah, in omogočili, da izvajajo matematične aktivnosti v domačem okolju. Na ta način smo želeli, da bi starši otrok, ki so sodelovali v raziskavi, izgradili pozitiven odnos do matematike, kar pozitivno vpliva na dosežke otrok pri matematiki (Bernie in Lall 2008). Z raziskavo smo želeli ugotoviti, ali naš pristop vključevanja staršev v poučevanje predšolske matematike njihovih otrok omogoča aktivno sodelovanje med starši in vzgojiteljem ter ali omogoča pomoč pri premagovanju strahov pred matematiko. Zato smo si zastavil naslednji raziskovalni vprašanji:

1. Kakšen odnos do matematike imajo starši pred in po izvedbi raziskave?

2. Ali so starši pripravljeni vključiti zgodnje matematične elemente $v$ domače okolje, če vedo, kako to storiti?

\section{Metodologija}

$\checkmark$ raziskavi smo uporabili deskriptivno metodo empiričnega pedagoškega raziskovanja.

$\checkmark$ raziskavo je bila vključena vrtčevska skupina prvega starostnega obdobja, $v$ kateri so bili otroci, stari od 1 do 3 leta. Najmlajši otrok je bil v času izvajanja raziskave star 1 leto in 1 mesec, najstarejši pa 2 leti in 11 mesecev. Sodelovalo je 9 otrok, od tega 3 dečki in 6 deklic ter 18 staršev, od tega 9 moških in 9 žensk.

Raziskava je potekala v šolskem letu 2017/2018. V začetni fazi smo preučili literaturo in pripravili gradiva za starše. Starši otrok vrtčevske skupine so bili deležni izobraževanja oz. priprav na eksperiment, v okviru katerega so bile organizirane delavnice, katerih namen je bil seznaniti starše z zgodnjo matematiko. Razdelili smo jim gradivo, ki smo ga poimenovali »matematični nahrbtnik« in ki jim je bilo v pomoč pri načrtovanju ter izvedbi matematične aktivnosti v domačem okolju. Vsebino »matematičnega nahrbtnika« sta pred- 
stavljala torbica, $v$ kateri so bile kartonke $z$ matematično vsebino, in zvezek $z$ izbranimi matematičnimi nalogami. Zvezek je vseboval 27 nalog s področja števil, geometrije, razvrščanja, urejanja in prirejanja ter kombinatorike, opremljene s fotografijami.

$\checkmark$ uvodnem delu zvezka so bili zapisani navodila za starše ter spletni naslov, kamor so lahko poslali poljubno fotografijo s komentarjem. Navodilo je staršem narekovalo, da si z otrokom izberejo nalogo iz zvezka in po otrokovih zmožnostih ustvarijo oz. izdelajo matematično igro, ki jo nato prinesejo $v$ vrtec.

Podatke smo zbrali kvalitativno, in sicer z opazovanjem in s pogovorom $\mathrm{s}$ starši. Pred in po izvedbi raziskave smo starše povprašali o njihovem odnosu do matematike. Pogovor je potekal individualno z vsakim staršem, saj smo želeli ugotovili vzroke za pozitiven oz. negativen odnos do matematike. Da bi pridobili mnenje staršev o ustreznosti našega pristopa, smo jih zaprosili, da nam povratne informacije o aktivnostih, izvedenih doma, posredujejo na dani spletni naslov.

\section{Razprava in evalvacija}

Pred izvedbo raziskave smo se pogovorili s starši glede njihovega odnosa do matematike. Ugotovili smo, da ima večina staršev (16) negativen odnos do matematike, ki izvira iz lastne negativne izkušnje oz. negotovosti glede svojih matematičnih znanj. Le dva starša poročata, da nimata ne pozitivnih in ne negativnih matematičnih izkušenj. Strinjamo se $s$ trditvijo B. Japelj Pavešić (2014), ki pravi, da lahko matematika zaradi svoje specifičnosti vzbuja nelagodje pri starših zaradi lastne nesamozavestni oz. pretekle izkušnje. Nekateri starši so namreč to trdtiev potrdili. Zavedati se moramo, da izkušnje staršev pomembno vplivajo na pripisovanje pomena pomembnosti matematičnemu znanju. Otrok, ki znanje usvoji, vendar ne dobi povratne informacije ali potrditve o svojem znanju od odrasle osebe, ki ji zaupa, ne bo začel ceniti svojega znanja (Japelj Pavešić 2014, 28). Poleg tega, ni dovolj, da vrtec otroku ponuja veliko odličnih priložnosti za učenje matematike, treba je narediti še naslednji korak: vključiti starše v prepoznavanje otrokovega znanja, dvigniti njihovo zanimanje za dosežke in izdelke njihovih otrok ter uskladiti pričakovanja do otrokovega napredovanja $v$ matematiki z njegovimi domačimi (Japelj Pavešić 2014, 28).

Vsi starši (18) izbrane vrtčevske skupine otrok so se udeležili matematičnih delavnic, kjer so dobili potrebne informacije glede izvedbe raziskave. Starši, ki so se udeležili delavnic, so bili tudi pripravljeni sodelovati v raziskavi. Pri tem so pokazali veliko mero ustvarjalnosti in angažiranosti: tako so starši 
Slika 1

Izdelava

matematično-didaktične igre
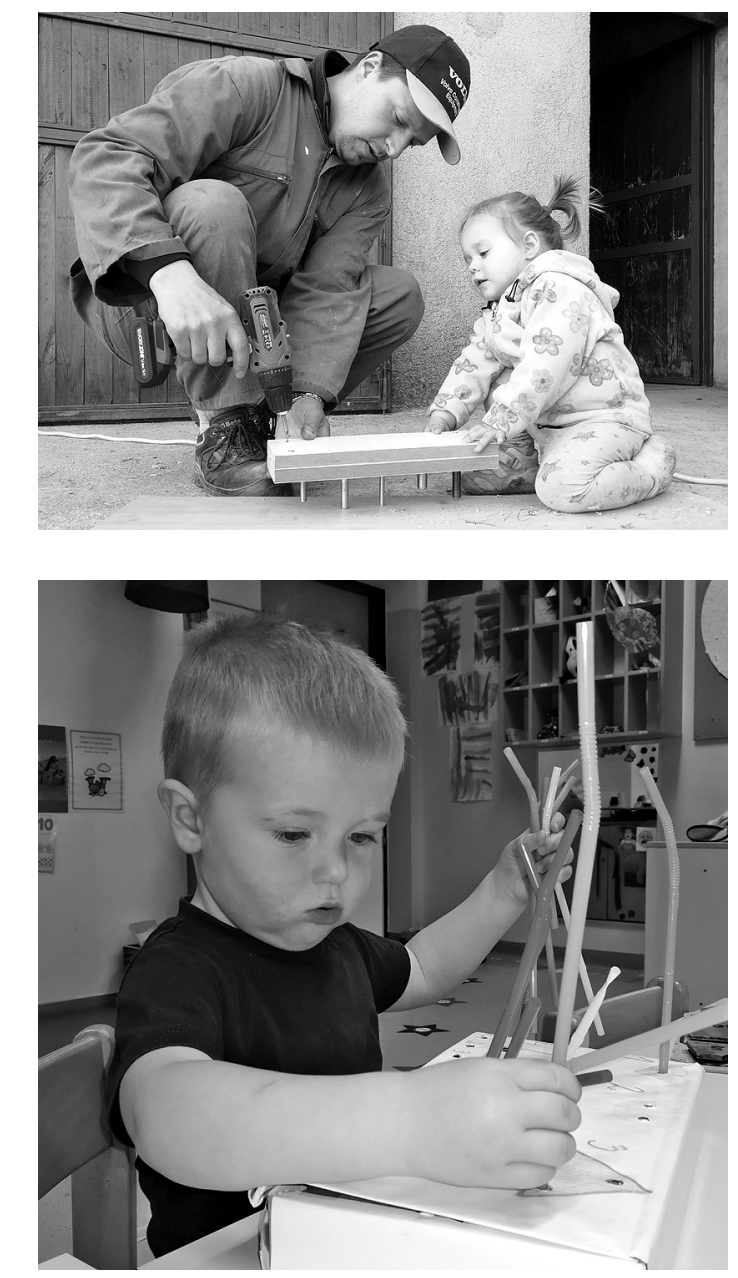

Slika 2

Igranje lastne igre

dveh otrok doma naredili po dve nalogi, starši treh otrok so uporabili predloge iz zvezka v nahrbtniku, starši šestih otrok pa so ustvarili svoje izvirne matematične igre. Vse igre, ki so jih ustvarili starši, so bile primerne za otroke in so pritegnile njihovo pozornost.

Med raziskavo smo starše prosili, da podajo svoje mnenje glede ustreznosti sodelovanja med starši in vrtcem na matematičnem področju. Poglejmo eno izmed mnenj, ki smo jih dobili v pisni obliki:

Iskreno povedano, da na prvo mi je bilo odveč, ker imam še dva šoloobvezna otroka. Rada se udeležim, če le imam čas. Hotela sem, da bo čisto nekaj drugačnega, kot je bilo prikazano na slikicah. In dobili smo 
Slika 3

Sodelovanje med otroki pri igri

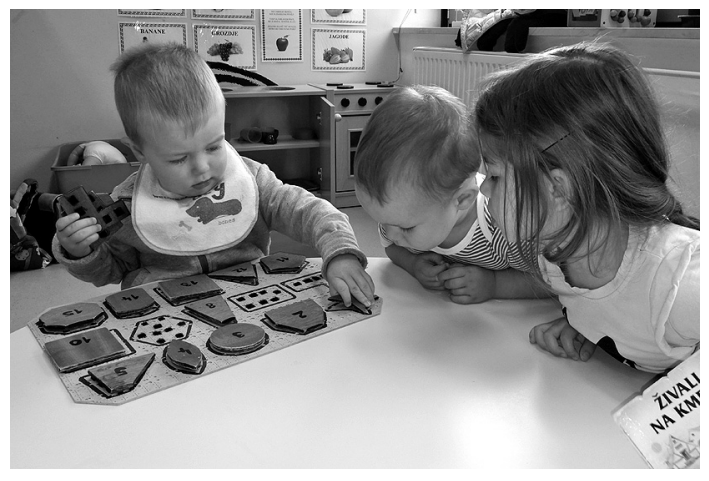

idejo. Vključili smo tudi očeta in na koncu bili navdušeni z izdelkom. Še najbolj pa A. Zaključek tega je, da je to odlično. (Mama 2,5-letne deklice)

Iz pisnih mnenj staršev o raziskavi lahko razberemo, da so pripravljeni in si želijo aktivno sodelovati z vrtcem, če se jim le ponudi ta možnost. Prednost takšnega sodelovanja je $v$ tem, da starši $z$ večjo povezanostjo in $s$ pogovori postajajo občutljivejši za otrokove socialne, intelektualne in čustvene potrebe. Starši na tak način pridobijo večje zaupanje vase in so se sposobni tudi pravilno odločati. Prav tako dobijo veliko koristnih informacij o razvoju njihovega otroka in tako začnejo uporabljati več pozitivnega spodbujanja in bolj spoštujejo delo vzgojiteljev (Lepičnik Vodopivec 2012, 13).

Z dejavnostmi »matematičnega nahrbtnika« smo želeli starše vključiti v načrtovanje učnega procesa, saj imajo pravico sodelovati pri načrtovanju življenja in dela v vrtcu in v oddelku. Načelo sodelovanja s starši (Ministrstvo za šolstvo in šport 1999, 8) razumemo kot načina prepletanja in razumevanja dveh svetov, ki otroku predstavljata skupen svet. Povezovanje s starši in izmenjavanje informacij o otrokovih dosežkih in sposobnostih za lažjo presojo o tem, kaj otrok zmore in kaj ga veseli, je ključno za spodbudno vzdušje pri matematičnih dejavnostih (Ministrstvo za šolstvo in šport 1999).

Cilj predšolske matematike je, da bi jo otrok doživljal kot prijetno izkušnjo (Ministrstvo za šolstvo in šport 1999). Vendar je treba dodati, tisti, ki jo lahko otrokom ponudi, odrasel. Otrokova sposobnost učenja se ob spodbudnem okolju lahko poveča tudi za četrtino (Bregant 2012, 299). Eden izmed načinov je, da v svojem okolju, preko vzgojitelja in staršev, pridobi izkušnje na konkretni ravni, s konkretnimi predmeti v različnih kontekstih, kjer s predmeti rokujejo, jih raziskujejo in se z njimi srečujejo ob vsakodnevnih situacijah. Znanje matematike navsezadnje ne pomeni samo reševanja matematičnih problemov, temveč komuniciranje, ocenjevanje in sklepanje, kar kot skupek pripo- 
more $\mathrm{h}$ konstruktivnemu in razmišljujočemu delovanju v naravnem, kulturnem in socialnem okolju (Nolimal 2012).

\section{Sklepne ugotovitve}

Pri sodelovanju s starši moramo iskati nove, spremenjene načine dela (Štular 1990) in starše sprejeti kot enakopravne sodelavce. Le tako bodo namreč začutili pomembnost ob skupnem načrtovanju in izvajanju vzgojnega dela ter lepoto in uživanje ob skupni igri z otroki. To smo, po mnenju staršev, dosegli z naš raziskavo.

Otrokov prvi stik z matematiko bo prijazen, če ga bo doživel celovito, preko občutkov, ki so mu blizu, ob katerih se počuti sproščeno in varno. Če mu bo uspelo ohraniti ta občutek, bo mnogo lažje premagoval ovire pri kasnejšem dojemanju vse zahtevnejših zakonitostih matematike, saj je vanjo vstopil skozi prava vrata (Zajc in Koželj 2001, 11).

Zavedamo se, da je bilo v našo raziskavo vključenih majhno število otrok in staršev, zato bi bilo potrebno raziskavo razširiti. Potrebovali bi več informacij o mnenjih in stališčih staršev o matematiki ter o celostnem sodelovanju staršev z vzgojitelji. Na tem mestu se odpirajo nova vprašanja, in sicer: ali si vsi starši želijo sodelovati in kdo so starši, ki si želijo sodelovati pri učenju svojih otrok? Poleg tega bi bilo treba preučiti še druge načine vpeljevanja zgodnje matematike $v$ sodelovanju s starši. Vrtec in starši imajo ključno vlogo pri matematičnem opismenjevanju, saj so prav matematične sposobnosti in veščine tiste, ki bodo vplivale na kasnejšo uspešnost otrok in s tem tudi države.

\section{Literatura}

Anning, A., in A. Edwards. 2006. Promoting Children's Learning Birth to Five: Developing the New Early Years Professional. 2. izd. Buckingham: Open University Press.

Bailey, D. H., S. R. Siegler in D. C. Geary. 2014. »Early Predictors of Middle School Fraction Knowledge.« Developmental Science 27 (5): 75-85.

Berkowitz, T., M. W. Schaeffer, E. A. Maloney, L. Peterson, C. Gregor, S. C. Levine in S. L. Beilock. 2016. »Math at Home Adds up to Achievement in School.» Science 350:196-198.

Bernie, J., in M. Lall. 2008. »Building Bridges between Home and School Mathematics: A Review of the Ocean Mathematics Project.« http://discovery.ucl .ac.uk/10004003/1/Building_Bridges.pdf

Biddulph, F., J. Biddulph in C. Biddulph. 2003. The Complexity of Community and Family Influences on Children's Achievement in New Zealand: Best Evidence Synthesis. Wellington, NZ: Ministry of Education. 
Bregant, T. 2012. »Učenje in možgani.«Proteus 74 (7): 295-303.

Cai, J. 2003. »Investigating Parental Roles in Students' Learning of Mathematics from a Cross-National Perspective.« Mathematics Education Research Journal 15 (2): 87-106.

Cannon, J., in H. P. Ginsburg, 2008. »'Doing the Math:' Maternal Beliefs about Early Mathematics versus Language Learning."Early Education and Development 19 (2): 238-260.

Claessens, A., G. Duncan in M. Engel. 2009. »Kindergarten Skills and Fifth-Grade Achievement: Evidence from the ECLS-K. « Economics of Education Review 28:415-427.

Claessens, A., M. Engel in F. C. Curran. 2014. »Academic Content, Student Learning, and the Persistence of Preschool Effects.« American Educational Research Journal 51 (2): 403-434.

Clements, D. H., in J. Sarama. 2014. Learning and Teaching Early Math: The Learning Trajectories Approach. New York, NY: Routledge.

Dickson, L., M. Brown in O. Gibson. 1984. Children Learning Mathematics: A Teacher's Guide to Recent Research. London: Cassell.

Duncan, G. J., C. J. Dowsett, A. Claessens, K. Magnuson, A. C. Huston, P. Klebanov in H. Sexton. 2007. "School Readiness and Later Achievement."Developmental Psychology 43 (6): 1428-1446.

Epstein, J. L. 1992. School and Family Partnership. Baltimore, MD: Center on Families, Schools, and Children's Learning.

Ginsburg, H. P., N. Inoue in K. H. Seo. 1999. "Young Children Doing Mathematics: Observations of Everyday Activities."V Mathematics in the Early Years, ur. J. V. Copley, 88-89. Reston, VA: National Council of Teachers of Mathematics.

Gopnik A., D. M. Sobel, L. E. Schulz in C. Glymour. 2001. »Causal Learning Mechanisms in Very Young Children: Two-, Three-, and Fouryear-Olds Infer Causal Relations from Patterns of Variation and Covariation." Developmental Psychology 37 (5): 620-629.

Harris, B., in D. Petersen. 2017. Developing Math Skills in Early Childhood. Issue Brief. Washington, DC: Mathematica Policy Research.

Harris, B., D. Petersen in C. Smither-Wulsin. 2017. Integrating Mathematical Thinking into Family Engagement Programs. Issue Brief. Washington, DC: Mathematica Policy Research.

Haylock, D. 2007. Mathematics Explained for Primary Teachers. 3. izd. Thousand Oaks, CA: Sage.

Hodnik Čadež, T., in V. Manfreda Kolar. 2009. »Didaktična sredstva z vidika motivacije pri pouku matematike.«V Poukv družbi znanja, ur. M. Cotič, V. Medved Udovič in M. Cencič, 232-247. Koper: Pedagoška fakulteta.

Japelj Pavešić, B., 2014. »Predšolsko znanje matematike v luči mednarodnih primerjav«. V Spodbujanje matematičnega mišljenja v vrtcu, ur. D. Belak, B. Vrbovšek in M. Domicilj, str. 18-30. Ljubljana: Supra. 
Jordan, N. C., D. Kaplan, C. Ramineni in M. N. Locuniak. 2009. »Early Math Matters: Kindergarten Number Competence and Later Mathematics Outcomes." Developmental Psychology 45 (3): 850-867.

Kunič, N. 2003. »Sodelovanje med vrtcem in starši.« Educa 12 (4): 13-17.

Ministrstvo za šolstvo in šport. 1999. Kurikulum za vrtce: predšolska vzgoja v vrtcih. Ljubljana: Ministrstvo za šolstvo in šport.

Lepičnik Vodopivec, J. 2012. Teorija in praksa sodelovanja s starši. Ljubljana: Pedagoška fakulteta.

Levine, S. C., L. W. Suriyakham, M. L. Rowe, J. Huttenlocher in E. A. Gunderson. 2010. »What Counts in the Development of Young Children's Number Knowledge?« Developmental Psychology 46: 1309-1319.

Logar, D. 2012. »Delovni odnosi med vzgojiteljem in starši.« V Sodelovanje med vrtcem in starši »družinami«, ur. M. Željeznov Seničar, 35-42. Ljubljana: MiB.

McCain, M. N., and J. F. Mustard. 1999. Early Years Study: Reversing the Real Brain Drain. Toronto: Publications Ontario.

McNeil N. M., in L. Jarvin. 2007. „When Theories Don't Add up: Disentangling the Manipulatives Debate." Theory into Practice: Research in the Service of Practice 46 (4): 309-316.

Melhuish, E. C., K. Sylva, P. Sammons, I. Siraj-Blatchford, B. Taggart in A. Malin. 2008. »Preschool Influences on Mathematics Achievement.«Science 321 (5893): 1161-1162.

Mešinović, S., M. Cotič in A. Žakelj. 2017. Učenje in poučevanje geometrije v osnovni šoli. Koper: Založba Univerze na Primorskem.

Morgan, A., in P. Tremere. 1993. »IMPACT: A Humberside perspective.« V Partherships in Maths: Parents and Schools; The IMPACT Project, ur. R. Merttens in J. Vass, 63-70. London, UK: Falmer.

Munn, P. 1997a. "Children's Beliefs about Couting." V Teaching and Learning Early Number, ur. I. Thompson, 19-33. Buckingham: Open University Press.

Munn, P. 1997b. »Writing and Number.« V Teaching and Learning Early Number, ur. I. Thompson, 9-19. Buckingham: Open University Press.

Murnane, R. J., J. B. Willett in F. Levy. 1995. "The Growing Importance of Cognitive skills in Wage Determination."Review of Economics and Statistics 78:251-266.

Nolimal, F. 2012. »Bralna pismenost kot opora naravoslovni in matematični pismenosti.« V Nacionalna konferenca Poti do kakovostnega znanja naravoslovja in matematike, Brdo pri Kranju, 11. in 12. december 2012, ur. M. Vidmar in T. Taštanoska, 23-26. Ljubljana: Ministrstvo Republike Slovenije za izobraževanje, znanost, kulturo in šport.

Onslow, B. 1992. »Improving the Attitude of Students and Parents through Family Involvement in Mathematics. "Mathematics Education Research Journal 4 (3): 24-31.

Pritchard, R. 2004. »Investigating Parental Attitudes and Beliefs in Mathematics 
Education."V Mathematics education for the third Millenium: Towards 2010, ur. I. Putt, R. Faragher in M. McLean, 478-485. Sydney: MERGA.

Rivera-Batiz, F. L. 1992. „Quantitative Literacy and the Likelihood of Employment among Young Adults in the United States." Journal of Human Resources 27:313-328.

Sarama, J., in D. H. Clements. 2009. Early Childhood Mathematics Education Research: Learning Trajectories for Young Children. New York: Routledge.

Saxe, G., S. Guberman in M. Gearhart. 1987. "Social Processes in Early Number Development."Monographs of the Society for Research in Child Development 52 (2): 100-200.

Starkey, P., in A. Klein. 2000. »Fostering Parental Support for Children's Mathematical Development: An Intervention with Head Start Families." Early Education and Development 11 (5): 659-680.

Štular, V. 1990. "Osnovni pogoji, ki omogočajo kreativno delo vzgojitelja.» V Vzgojitelj: kreator predšolske vzgoje, ur. M. Blažič, 221-225. Novo mesto: Skupnost varstvenih organizacij.

Tye, C. 1993. »IMPACT and the Early Years Classroom. V Partnerships in Maths: Parents and Schools; The IMPACT Project, ur. R. Merttens in J. Vass, 37-44. London, UK: Falmer.

Zajc, I., in M. Koželj. 2001. Matematika v srcu umetnosti. Ljubljana: Jutro.

Zigler, E., W. Gilliam in S. A. Jones. 2006. Vision for Universal Preschool Education. New York: Cambridge University Press.

Watts, T. W., G. J. Duncan, R. S. Siegler in P. E. Davis-Kean. 2014. „What's Past Is Prologue: Relations Between Early Mathematics Knowledge and High, School Achievement.« Educational Research 43 (7): 352-360.

\section{Involving Parents in Early Learning of Mathematics}

In the recent years, the general public has been paying more attention to mathematical literacy. A number of studies from around the world have shown that the mathematical knowledge children acquire could predict their future careers. Mathematical knowledge can affect their subsequent level of education, academic success, job quality, or even determine their wages. Some research has shown that the mathematical knowledge with children is supposed to be a powerful predictor of their socioeconomic status later in life. Facilitating mathematical literacy is a long-term process, which begins in pre-school. During this period, their parents and home environment prove to be the greatest influencers on their development, and thus the development of their abilities in mathematical thinking. Therefore, the involvement of parents in early learning of mathematics is crucial. For this purpose, we have designed and implemented the research, through which we taught the parents how to play with early mathematics and made it possible for children to explore certain mathematical concepts in interaction with their parents within their home environ- 
ment. We have found that parents want to be the co-creators of their children's knowledge and that they are willing to cooperate with kindergartens, but wish to receive guidelines on implementation.

Keywords: early childhood education, early mathematics, home environment, parents, mathematical backpack 